\title{
New Normal and Social Change in Indonesia Society
}

\author{
Putu Nadia Aurelia Tasya ${ }^{*}$ \\ ${ }^{1}$ Universitas Pendidikan Ganesha, Indonesia \\ *e-mail: nadiatasya1705@gmail.com \\ Article history: Received 15 December 2020; Accepted 31 March 2021; Available online 30 April 2021
}

\begin{abstract}
The world is currently experiencing a disastrous disease outbreak that is very disturbing to humans, namely the Coronavirus outbreak. This virus originates and originates from the city of Wuhan, China. Another name for Coronavirus

Keywords: New Era; Pandemic; Social Change is the Covid-19 outbreak. Indonesia is one of the countries in the world affected by this virus until it has entered a pandemic status. The Indonesian government and the people have tried their best to fight this pandemic and many policies have been issued regarding health protocols to protect the nation from this very fast-spreading disease outbreak. One of the policies issued is the new normal, which is a situation where all community activities can be carried out as usual but are still required to comply with existing regulations. For examples, wearing a mask, staying away from the crowd, and washing your hands cleanly. It cannot be denied that this policy can bring about social changes or changes in habits in society towards a society that is responsive to health, hygienic, and cares for the environment.
\end{abstract}

\section{Introduction}

From early 2020 until almost the end of this year, the world is facing an epidemic called Covid-19. Another name for Covid-19 is Corona Virus. This virus originated from Wuhan City, China. Since the outbreak of this virus in the city, the local government has quickly taken an action to carry out a lockdown to prevent the spread of the virus further. Various ways have been made in efforts to prevent it, but as it is known that viruses are invisible microorganisms and humans cannot feel this presence unless they have been infected by the virus. Due to the nature of the virus, the spread of the virus cannot be controlled and attacks all countries around the world. So, it can be concluded that the whole countries experience a health crisis once in a century and the effects of this will be felt for the next few decades or it is called a pandemic.

Indonesia is one of the countries affected by the Covid-19 pandemic. The case of the spread of this virus began to spread hardly in March 2020, where the number of positive cases of Coronavirus is increasing day by day. The Indonesian government has been trying so hard to combat the disease outbreak. All policies have been issued, ranging from limiting outdoor social activities, working from home, implementing strict health protocols, and closing all public facilities. The readiness of the government and the Indonesian people to spread this disease greatly affects all aspects of the nation's life. Until June 2020, Indonesia has started to implement the new normal era and opened several public places, and people are allowed to do some 
activities outside the home. However, all such concessions must still comply with the health protocols that have been enforced. Policies to comply with protocols are such as wearing a mask when doing outdoor activities, staying away from large crowds, limiting activities, preparing hand sanitizers, and always washing hands cleanly.

All the regulations that are issued unconsciously create new habits in society. Social changes that occur in society cannot be hidden and basically, the people of a country will always experience change. New normal and social changes that occur today influence each other and will be discussed more deeply in this paper with several problem formulations that have been prepared. As for the formulation of the problem on the subject of this paper, namely, what is the current Indonesian government policy in facing the pandemic? And what is the effect of the new normal on social changes that occur in society? The purpose of discussing the problems in this paper is to find out about the steps of the Indonesian government along with the policies issued in dealing with the Covid-19 pandemic in the new normal era and to examine in more detail the influence of the new normal life order on social dynamics that occur in society.

\section{Theoritical Review}

The new era is an era where humans as a society carry out new structures, habits, and behaviors based on adaptation to cultivate clean and healthy living habits. The new life order has a tendency to live healthier by washing hands regularly with soap, wearing masks when outside the home, maintaining a safe distance, and avoiding crowds. It is hoped that the implementation of the new normal policy will run well. All parties managing public places, workplaces, schools, and places of worship must always pay attention to this aspect of the health protocol and the public must also be disciplined in this regard. To realize the new normal, the government has invited all parties, such as the public, experts, and experts to formulate health protocols to ensure that people can return to their activities and be protected from Covid-19.

A pandemic is a global or world disease outbreak. According to the World Health Organization (WHO), a pandemic is declared when a disease has spread around the world and has crossed borders. An epidemic that is categorized as a pandemic is a disease that is contagious and has an ongoing infection status. Pandemics are initially classified as epidemics where the disease spreads very rapidly from one area to a certain area. Covid-19 is a disease outbreak that started as an epidemic in China before spreading around the world and becoming a pandemic. But keep in mind that an epidemic is not always a pandemic.

Social change is all changes that occur in social institutions in a society that can affect the social system, including values, social attitudes, and patterns of behavior among groups in society. Every individual or society must always experience changes in the community or family environment. Social change is different from other changes. The difference is that social change emphasizes changes that occur in the cultural and structural aspects of society. The impact of social life is the result of social change. So that it can realize a better life and dignity. Social change is also driven by factors of ideological, economic, and political movements.

\section{Result and Discussion}

\section{The Current Indonesian Government Policy In Facing The Pandemic}

All countries around the world, including Indonesia, have experienced a pandemic for almost a year 2020. The impact of the Coronavirus is felt by the Indonesian people in terms of health, economy, social, politics, development, and education. As a country that is based on law and the implementation of policies is the right way for Indonesia to deal with this pandemic, as well as other countries. The Indonesian government has issued various policies to overcome the Coronavirus pandemic with health protocols, large-scale social restrictions, and social assistance programs. The Indonesian government has made very maximum efforts to reduce the negative 
effects of this epidemic, one of which is by limiting community activities. However, every day some obstacles cause the policy not to be implemented smoothly. Constraints are mentioned because considering the economic cycle of the nation and state must continue to run and people must continue to meet their daily needs by earning income, while the government will not be able to provide social assistance to the community forever. This condition seems to create a big dilemma for the state and society. Therefore, the government issued a new normal policy to deal with the Coronavirus. New normal is a policy issued to reopen socio-economic activities and public activities but still on a limited basis while still using health standards. Living in the new normal era is a community adaptation process to start new habits to save people's lives and prevent the spread of the Coronavirus. This new normal policy is carried out as long as the virus vaccine has not been found, and so that the economy of the people and the country must continue to run because it is also impossible for residents to continue to stay at home without an uncertain situation. From a government perspective, the new normal policy is intended so that the state can carry out its functions under the prevailing law or constitution.

\section{The Effect Of The New Normal On Social Changes That Occur In Society}

In social life, of course, we are familiar with events of social change. The social changes that occur must be balanced with a process of adaptation so that all these changes can be attached to the community and culture. It is really necessary to have strict habits to create a culture. This is where we are all now, in the new normal era, which is one of the changes that occur in society. Various adjustments in the attitudes and behavior of everyday life made in the new normal are the habit of using masks when traveling, diligently washing hands, and avoiding crowds. Changes in habits that occur are a response from the community to the actual situation that occurs. During the new normal period, there were many changes in habits, such as people who had never worn a mask since the new normal era began, many people even almost entirely wore masks, people became more aware of a culture of healthy living such as diligently exercising and eating healthy food strongly demanded to comply with the rules established by the government in enforcing health protocols. Not only changes in the health sector have occurred, but significant effects are also felt in the education sector. Changes in the education system, which were originally carried out face-to-face, are now being transferred to an online system with the concept of learning from home.

\section{Conclusion}

During this full year, the Covid-19 pandemic virus has attacked all countries around the world, including Indonesia. Many changes have occurred as a result of this disease outbreak. The impact of the Coronavirus is felt by the Indonesian people in terms of health, economy, social, politics, development, and education. One of the most significant impacts that occur in society is the social change created by the new normal era. The new era is an era where humans as a society carry out new structures, habits, and behaviors based on adaptation to cultivate clean and healthy living habits. The new life order has a tendency to live healthier by washing hands regularly with soap, wearing masks when outside the home, maintaining a safe distance, and avoiding crowds. This is where we are all now, in the new normal era, which is one of the changes that occur in society.

\section{Reference}

Dipna, V. P. (2020). Arti New Normal Indonesia: Tatanan Baru Beradaptasi dengan Covid-19 (https://tirto.id/arti-new-normal-indonesia-tatanan-baru-beradaptasi-dengan-covid-19fDB3, accessed on Oktober 11th 2020).

Henny, A. D. (2020). Dampak Pandemi Covid-19 Terhadap Perubahan Sosial New Normal (https://www.kompasiana.com/henny90808/5f397f36d541df76e37278d2/dampak- 
pandemi-covid-19-terhadap-perubahan-sosial-new-normal?page=all, accessed on Oktober 11th 2020).

Widodo, I. (2020). WHO: Dampak Covid-19 Akan terasa Sampai Beberapa Dekade ke Depan (https://www.timesindonesia.co.id/read/news/288330/who-dampak-covid19-akanterasa-sampai-beberapa-dekade-ke-depan, accessed on Oktober 11th 2020). 